\title{
Is it only osteoporosis? An endocrine perspective on a case of multiple myeloma
}

\author{
Assist. Prof. Mara CARSOTE ${ }^{1,2}$, Anda DUMITRASCU ${ }^{2}, \mathrm{MD}, \mathrm{PhD}$, Andra COCOLOS ${ }^{1,2}, \mathrm{MD}, \mathrm{PhD}$ student, \\ Nicoleta DUMITRU ${ }^{1,2}, \mathrm{MD}, \mathrm{PhD}$ student, Assist. Prof. Eugenia PETROVA ${ }^{1,2}, \mathrm{MD}, \mathrm{PhD}$, \\ Lecturer Ana VALEA ${ }^{3,4}, \mathrm{MD}, \mathrm{PhD}$, Assoc. Prof. Adina GHEMIGIAN ${ }^{1,2}, \mathrm{MD}, \mathrm{PhD}$ \\ 1"Carol Davila" University of Medicine and Pharmacy, Bucharest \\ 2"C.I. Parhon" National Institute of Endocrinology, Bucharest \\ "I. Hatieganu" University of Medicine and Pharmacy, Cluj-Napoca \\ ${ }^{4}$ Clinical County Hospital, Cluj-Napoca
}

\begin{abstract}
Introduction. Multiple myeloma represents a malignant skeleton condition, been considered the most frequent bone malignancy of primary type in people older than 70 years. Myeloma causes a particular deterioration of bone via bone loss which can be localized or diffuse. The skeletal anomalies may include osteoporosis and vertebral fractures as first sign of the condition which need to be differentiated from others types of osteoporosis. This is a case presentation. This is a 56-year old female who was diagnosed with a lumbar fracture 5 months ago and considered osteoporosis treated with alendronate. Bone pain continued in addition to hypoanabolic syndrome. Second opinion showed hypercalcemia with suppressed parathomone and high bone resorption marker CrossLaps in association with mild anaemia, highly increased ESR (erythrocyte sedimentation rate), and newly discovered renal failure, and large ostolytic lesions at computed tomography. A bone biopsy was necessary and confirmed multiple myeloma.

Conclusion. Severe diagnosis like malignant bone conditions may be first diagnosed as osteoporosis.
\end{abstract}

Keywords: multiple myeloma, fracture, hypercalcemia

\section{INTRODUCTION}

Multiple myeloma represents a malignant skeleton condition, been considered the most frequent bone malignancy of primary type in people older than 70 years, with a recent increasing incidence $(1,2)$. Despite its heterogeneity of genomic configuration, modern advances on understanding the pathogenesis of the condition and further applications on practical management has been done $(2,3)$.

Therapeutically options varied over the time since the 1960s where melphalan and cyclo- phosphamide were used, later in the 1970s and 1980s mephalan and corticotherapy were considered gold options, then in 1990s the introduction of autologous hematopoietic stem cell improved the survive; in the 2000s there was the introduction of thalidomide analogues as well as proteosome inhibitors $(1,2)$.

Myeloma causes a particular deterioration of bone via bone loss which can be localized or diffuse $(3,4)$. The bone mass displacement causes a rise of blood calcium levels in association with bone loss-associated pain, and, in cases with vertebral involvement, spinal cord com- 
pression $(3,4)$. Hypercalcemia suppresses parathormone levels $(3,4)$. The skeletal anomalies may include osteoporosis and vertebral fractures as first sign of the condition $(3,4)$. They need to be differentiated from osteoporosis of other causes as primary osteoporosis (related to menopause or advanced age), or tumours related osteoporosis, or glucocorticoid- induced bone loss (5-7). We aim to introduce an adult female case with the mentioned bone condition after she was considered only osteoporotic. This is a case presentation. The patient signed for anonymously use of her medical records. She was admitted in different medical centres from Romania.

\section{CASE REPORT}

This is a 56-year old female (non-smoker, coming from endemic area, with negative personal and family medical history) who was diagnosed with a lumbar fracture (at L2 level) 5 months ago. She did not suffer any fall and the diagnosis of osteoporosis was established at the moment. She was offered weekly alendronate in addition to 500 units of cholecalciferol per day and symptomatic pain medication. She continued to feel bone pain especially at lumbar area but not exclusively. Further on, she started to lose weight (5 kilos within 5 months), with asthenia, chronic fatigue, loss of appetite, progressive pale skin and mild walking difficulties. So she was referred for a second opinion to a tertiary centre of endocrinology.

On admission, blood assays identified hypercalcemia with suppressed parathomone and high bone resorption marker CrossLaps in association with mild anaemia, highly increased ESR (erythrocyte sedimentation rate), and newly discovered renal failure (Table 1). Plane X-Ray of the spine confirmed lumbar L2 vertebral fracture (Fig. 1). T-score at central DXA (Dual-Energy $X$-Ray Absorptiometry) sustain the clinical diagnosis of osteoporosis (Table 2). Computed tomography without intravenous contrast showed large areas of osteolysis at first sacral vertebra of 2.3 by $4.3 \mathrm{~cm}$, at right iliac bone up to sacrum of 3.1 by 3.7 by $10.4 \mathrm{~cm}$ (Fig. 2). Multiple myeloma was suggested under these circumstances and the patient was further referred to haematological team. A bone biopsy confirmed it (of microcellular type) and she started specific oncologic protocol.
TABLE 1. Bone metabolism on a 56-year old female confirmed with multiple myeloma after prior diagnosis of severe osteoporosis

\begin{tabular}{|l|c|c|c|}
\hline Parameter & Value & $\begin{array}{c}\text { Normal } \\
\text { ranges }\end{array}$ & Units \\
\hline $\begin{array}{l}\text { Total serum } \\
\text { calcium }\end{array}$ & \multicolumn{2}{|c|}{$11.78 .4-10.2$} & $\mathrm{mg} / \mathrm{dl}$ \\
\hline $\begin{array}{l}\text { lonic serum } \\
\text { calcium }\end{array}$ & 4.44 & $3.9-4.9$ & $\mathrm{mg} / \mathrm{dl}$ \\
\hline $\begin{array}{l}\text { Alkaline } \\
\text { phosphatase }\end{array}$ & 108 & $40-150$ & $\mathrm{U} / \mathrm{l}$ \\
\hline osteocalcin & 33.29 & $14-46$ & $\mathrm{ng} / \mathrm{ml}$ \\
\hline CrossLaps & 2.91 & $0.104-0.504$ & $\mathrm{ng} / \mathrm{ml}$ \\
\hline P1NP & 66.31 & $15-74$ & $\mathrm{ng} / \mathrm{ml}$ \\
\hline $\begin{array}{l}\text { 25-hydroxyvitamin } \\
\text { D }\end{array}$ & 75.40 & $30-100$ & $\mathrm{ng} / \mathrm{ml}$ \\
\hline parathormone & 9.61 & $15-65$ & $\mathrm{pg} / \mathrm{ml}$ \\
\hline creatinine & 3.71 & $0.5-1.2$ & $\mathrm{mg} / \mathrm{dl}$ \\
\hline urea & 86 & $22-43$ & $\mathrm{mg} / \mathrm{dl}$ \\
\hline Haemoglobin & 10.5 & $12-15.5$ & $\mathrm{~g} / \mathrm{dl}$ \\
\hline ESR & 99 & $1-25$ & $\mathrm{~mm} / 1-\mathrm{hour}$ \\
\hline
\end{tabular}

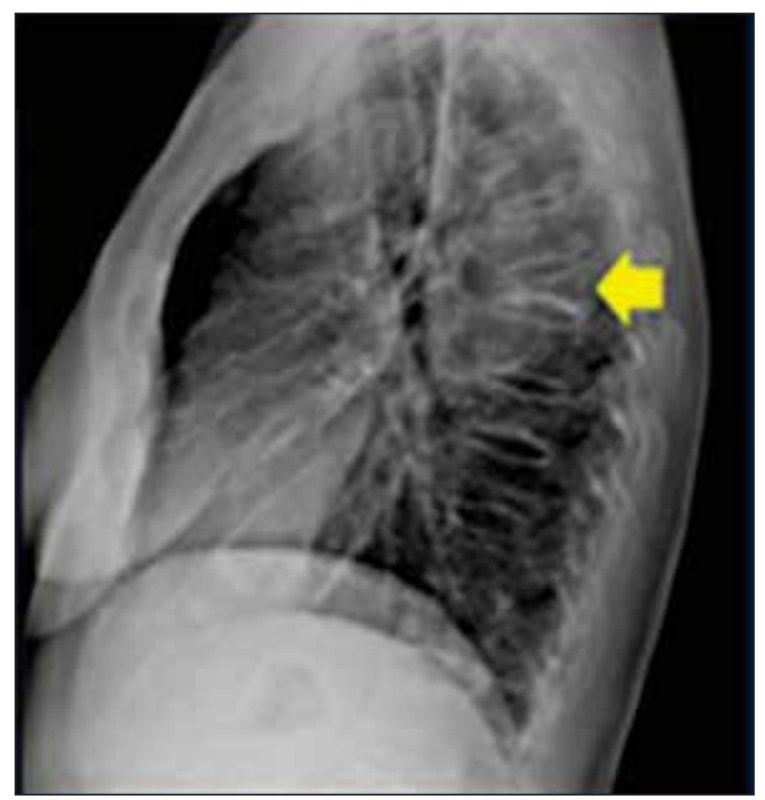

FIGURE 1. L2 lumbar vertebra fracture on a female patient with multiple myeloma

TABLE 2. Central DXA results on a 56-year old female confirmed with multiple myeloma after prior diagnosis of severe osteoporosis

\begin{tabular}{|l|c|c|c|}
\hline Region & $\begin{array}{c}\text { Bone mineral } \\
\text { density }\end{array}$ & T-score & Z-score \\
\hline L1-4 lumbar & 0.694 & -4.1 & -2.9 \\
\hline Femoral neck & 0.748 & -2.1 & -0.9 \\
\hline Total hip & 0.794 & -1.7 & -0.8 \\
\hline 1/3 distal radius & 0.501 & -3 & -2.4 \\
\hline
\end{tabular}

\section{DISCUSSION}

This case report introduces multiple myeloma, initially diagnosed as osteoporosis compli- 


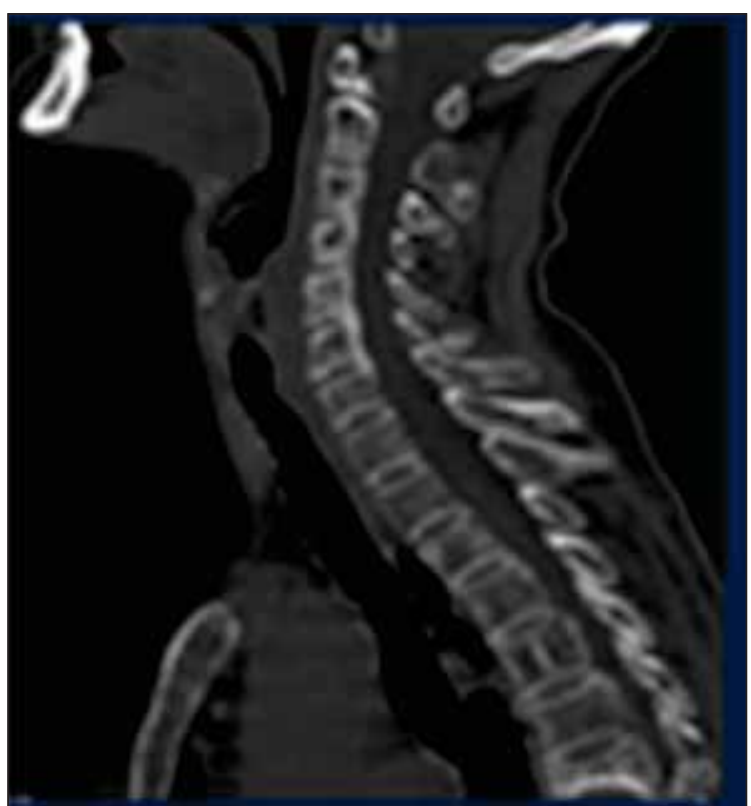

FIGURE 2. Similar aspect as Figure 1 at computed tomography

cated with a vertebral fracture. This is an endocrine perspective with importance for daily practice. The condition is complex underlying a heterogeneous molecular biology. Bone loss is caused by a cocktail of bone-derived factors with stimulatory effects on osteoclasts (like
RANKL, TNF alpha, IL-6), and inhibitory actions on osteoblasts (as Dkk-1, HGF) (4). This factors are produced by bone marrow or by plasma cells of malignant profile (4). They cause abnormal coupling of bone formation and resorption as seen in normal bone remodelling of healthy people (4). In this particular case, the patient was considered only osteoporotic until complex clinical picture required further investigations and therapies. The second option in her case does not include teriparatide as feasible option because of bone malignancy etiology (8).

The management includes drugs for pain control, bisphosphonates as main line of treatment which unfortunately does not entirely control the condition and they may associate severe adverse effects as seen in female patients with mammary cancer under therapy with aromatase inhibitors $(4,9)$. Denosumab might represent an alternative (10). Future perspectives introduce osteoanabolic therapies as inhibitors of Dkk-1 or sclerostin or HGF (4).

\section{CONCLUSION}

Severe diagnosis like malignant bone conditions may be first diagnosed as osteoporosis.

\section{REFERNCES}

1. Reisenbuckler $\mathbf{C}$. Multiple myeloma and diagnostic imaging. Radiol Technol. 2014 Mar-Apr; 85(4):391-410; quiz 411-3.

2. Bergsagel P.L. Where we were, where we are, where we are going: Progress in multiple myeloma. Am Soc Clin Oncol Educ Book. 2014:199-203.

3. Soekojo C.Y., de Mel S., Ooi M., Yan B., Chng W.J. Potential Clinical Application of Genomics in Multiple Myeloma. Int $\mathrm{J} \mathrm{Mol}$ Sci. 2018 Jun 10;19(6). pii: E1721. doi: 10.3390/ijms19061721.

4. Walker R.E., Lawson M.A., Buckle C.H., Snowden J.A., Chantry A.D. Myeloma bone disease: Pathogenesis, current treatments and future targets. Br Med Bull. 2014 Sep;111(1):117-38.

5. Gheorghisan-Galateanu A.A., Carsote M., Radoi V., Terzea D., Dumitrascu A.,
Albu S.E., Ghemigian A., Valea A. Menopausal osteoporosis in patients with bilateral adrenal tumors. Archives of Balkan Medical Union (The Official Journal of the Balkan Medical Union). 2016; 51(1):146150.

6. Ulmeanu R., Muntean R.A., Valea A., Carsote M. Glucocorticoid-induced osteoporosis after three decades of selfmedication for asthma. Medicine in evolution. 2016. XXII(4):494-497.

7. Vasiliu C., Carsote M., Valea A., Albu S.E., Grigoriu C., Ghemigian A. From benign lymphoid hyperplasia of the tongue base to iatrogenic hypothyroidism and severe menopausal osteoporosis. Ginecologia.ro. 2016 (an IV). 13(3):58-60.

8. Carsote M., Ghemigian A., Radu O., Valea A. Teriparatide as option for severe osteoporosis. Journal of Medical Practice (Practica Medicala). 2016; 4(47)-11:324330.

9. Dumitrache C., Paun D., Carsote M., Ghemigian A., Valea A. Therapy with zolendronic acid for menopausal osteoporosis: foccus on patients with breast cancer. Current Health Sciences Journal. 2016; 42(S5):28-30

10. Goldstein D.A. Denosumab for bone lesions in multiple myeloma - what is its value? Haematologica. 2018 May; 103(5):753-754. doi: 10.3324/ haematol.2017.185264. 